\title{
A new class of efficient 4-[(nitro substituted-phenyl)-hydrazonomethyl]- 1-phenyl-1H-pyrazole-3-carboxylate derived colorimetric chemosensor for selective sensing of fluoride and other biologically important anions
}

\author{
SUMAN SWAMI, ARUNAVA AGARWALA, BABITA MALIK and RAHUL SHRIVASTAVA* \\ Department of Chemistry, Manipal University Jaipur, VPO-Dehmi Kalan, Teshil-Sanganer, Off Jaipur Ajmer \\ Expressway, Jaipur, Rajasthan, 303 007, India \\ e-mail: chem.rahul@gmail.com
}

MS received 20 April 2016; revised 11 July 2016; accepted 11 July 2016

\begin{abstract}
A new class of efficient colorimetric chemosensors derived from 4-[(nitro substituted-phenyl)hydrazonomethyl]-1-phenyl-1 $H$-pyrazole-3-carboxylate have been synthesized and characterized. The synthesized receptors exhibit instant color change from yellow to dark purple along with significant bathochromic shifts when interacted with fluoride ions. The UV-Visible and ${ }^{1} \mathrm{H}$ NMR titration experiments revealed that 4-[(4-nitro-phenyl)-hydrazonomethyl]-1-phenyl- $1 \mathrm{H}$-pyrazole-3-carboxylate derivatives showed selective sensing of fluoride ions in preference to $\mathrm{Cl}^{-}, \mathrm{Br}^{-}, \mathrm{I}^{-}, \mathrm{PF}_{6}^{-}, \mathrm{HSO}_{4}^{-}, \mathrm{ClO}_{4}^{-}, \mathrm{CH}_{3} \mathrm{COO}^{-}$and $\mathrm{H}_{2} \mathrm{PO}_{4}^{-}$ions while 4-[2,4-dinitro-phenyl)-hydrazonomethyl]-1-phenyl-1H-pyrazole-3-carboxylate derivatives showed sensing of acetate, dihydrogen phosphate ion and fluoride ion in organic media.
\end{abstract}

Keywords. Pyrazole; receptor; sensor; anions; fluoride ion.

\section{Introduction}

The selective sensing of anionic species through artificial receptors have gained immense interest in the recent past $^{1}$ due to involvement of various anions in biological, chemical, environmental and pathological events of varying complexity. ${ }^{2}$ Among the biologically important anions, sensing of fluoride ions is a significant research area $^{3}$ because of its functional diversity which is both beneficial and detrimental. For example, it is wellestablished that fluoride ion plays important role in preventing dental caries and treatment of osteoporosis ${ }^{4}$ while excess of fluoride ion causes several adverse effects like fluorosis, kidney disorder, bone and skeletal cancer. ${ }^{5}$ Amongst several approaches adopted ${ }^{6}$ for the development of fluoride ion receptors, sensing of fluoride through colorimetric neutral receptors seems to be of utmost significance as they require minimum instrumentation and quick response through anion induced color changes of solution. ${ }^{7}$ Previous reports on colorimetric sensing of fluoride ions ${ }^{8}$ include molecular hosts having precise alignment of optical signaling chromophoric units with suitable anion binding sites such as urea, thiourea, amide and sulfonamides, which can provide one or more $\mathrm{H}$-bond donor sites for selective recognition of anionic species through $\mathrm{N}-\mathrm{H}-\mathrm{X}$ hydrogen

*For correspondence bonds. ${ }^{9}$ The interaction of anion with receptor triggers a change in photophysical response of the chromophoric unit to allow sensing through visual color changes. ${ }^{10}$ The selectivity and colorimetric response of receptors depend on the structure of the hydrogen bond complexes and basicity of anions. Among the anions, fluoride ion, usually forms strong hydrogen bond with a hydrogen bond donor fragment of the artificial receptor at lower concentration, and at higher concentration the interaction would likely stimulate the proton transfer reaction, which depends on the acidity of hydrogen bond donor group of the receptor. The colorimetric sensors based on the deprotonation of the binding moiety by anions are highly sensitive and selective in nature.

Heterocyclic systems like imidazole, pyrrole, naphthyridine, pyrazole etc., belong to an important class of nitrogen containing systems and they are of considerable pharmacological interest in view of their uses as anti-microbial, ${ }^{11 \mathrm{a}}$ anti-cancer, ${ }^{11 \mathrm{~b}}$ anti-inflammatory, ${ }^{11 \mathrm{c}}$ anti-tubercular, ${ }^{11 \mathrm{~d}}$ anti-parasitic, ${ }^{11 \mathrm{e}}$ anti-pyretic ${ }^{11 \mathrm{f}}$ and anti-fungal $^{11 \mathrm{~g}}$ agents. In continuation of our work on anion sensing, ${ }^{12}$ it was envisaged that functionalized pyrazole derivative like 4-formyl-3-carboxylate pyrazole might display interesting anion binding and sensing characteristic because of its structural features which involve methine proton of pyrazole and basic hydrogen bond acceptor fragment in condensed heterocyclic system integrated with formyl and ester 
functionality which can be modulated for the construction of effective recognition sites for noncovalent interactions. In this paper, we report the synthesis of pyrazole based molecular receptors for sensing of fluoride ion and other biologically and environmentally important anions. To design the receptors, we introduced hydrazone functionality substituted with electron withdrawing nitro unit which are probably responsible for the changes in color as well as to increase hydrogen bond donor tendency. ${ }^{12,13}$ It has been observed that these synthesized receptor molecules (5a and $\mathbf{5 e}$ ) exhibit significant binding ability for fluoride ions in preference to other anions which include $\mathrm{Cl}^{-}, \mathrm{Br}^{-}, \mathrm{I}^{-}$, $\mathrm{H}_{2} \mathrm{PO}_{4}^{-}, \mathrm{HSO}_{4}^{-}, \mathrm{CH}_{3} \mathrm{COO}^{-}, \mathrm{ClO}_{4}^{-}$and $\mathrm{PF}_{6}^{-}$.

\section{Experimental}

\subsection{General procedure for the synthesis of $\mathbf{4 a}$}

To a cooled and anhydrous dimethylformamide (80 $\mathrm{mL}), \mathrm{POCl}_{3}(25.5 \mathrm{~mL})$ was added drop wise at $0^{\circ} \mathrm{C}$ and stirred the reaction mixture for $30 \mathrm{~min}$ at same temperature. Phenyl hydrazone (13.5 g, $1 \mathrm{mmol}$ ) (3a) was added at $0^{\circ} \mathrm{C}$. The reaction mixture was stirred at room temperature for $2 \mathrm{~h}$. After completion of reaction as monitored by TLC, the reaction mixture was poured over crushed ice under stirring. Thereafter the mixture was neutralized with $10 \% \mathrm{NaHCO}_{3}$ solution which resulted in the formation of white solid. The solid product was filtered under vacuum and dried in air to give a compound $\mathbf{4 a}$.

\subsection{General procedure for the synthesis of $\mathbf{5 a}$}

To $4 \mathbf{a}(1 \mathrm{~g}, 4.1 \mathrm{mmol})$ in $20 \mathrm{~mL}$ ethanol, 4-nitro phenylhydrazine $(0.736 \mathrm{~g}, 4.8 \mathrm{mmol})$ was added. The reaction mixture was refluxed for $45 \mathrm{~min}$ and then cooled to room temperature. A yellow solid product was filtered off, washed with hot ethanol $(3 \times 10 \mathrm{~mL})$ and then dried under vacuum to give desired compound 5a as yellow solid. Selected analytical data for compounds 5a and 5e are given below: Compound 5a: Yield (90\%); M.p.: $238^{\circ} \mathrm{C}$; IR (KBr), $v_{\max }\left(\mathrm{cm}^{-1}\right)$ : 1605 $(\mathrm{C}=\mathrm{N}), 1704(\mathrm{C}=\mathrm{O})$. TOF-MS ES+ m/z calcd: 379.37 . found: $380.23(\mathrm{M}+1)$; Anal. Calcd.for $\mathrm{C}_{19} \mathrm{H}_{17} \mathrm{~N}_{5} \mathrm{O}_{4}$ : C 60.15, H 4.52, N 18.46, O 16.87\%. Found: C 60.08, H 4.36, N 18.35\%; ${ }^{1} \mathrm{H}$ NMR (400 MHz, $\left.\mathrm{CDCl}_{3}\right): \delta 1.41$ (t, $\left.3 \mathrm{H}, \mathrm{COOCH}_{2} \mathrm{CH}_{3}\right), \delta 4.42$ (q, $\left.2 \mathrm{H}, \mathrm{COOCH}_{2} \mathrm{CH}_{3}\right), \delta$ $7.14(\mathrm{~d}, 1 \mathrm{H}, \mathrm{ArH}), \delta 7.36(\mathrm{~m}, 2 \mathrm{H}, \mathrm{ArH}), \delta 7.47-7.51(\mathrm{~m}$, $2 \mathrm{H}, \mathrm{ArH}), \delta 7.77\left(\mathrm{~d}, 2 \mathrm{H}, \mathrm{ArH}_{\text {nitrophenyl }}\right), \delta 8.11(\mathrm{~d}, 2 \mathrm{H}$, $\left.\mathrm{ArH}_{\text {nitrophenyl }}\right), \delta$ 8.41(bs, $2 \mathrm{H}, \mathrm{CH}_{\text {pyrazole }}+\mathrm{CH}_{\text {azomethine }}$ ), $10.45(\mathrm{~s}, 1 \mathrm{H}, \mathrm{NH}) .{ }^{13} \mathrm{C} \mathrm{NMR}\left(\mathrm{CDCl}_{3}\right): 14.2,60.8$,
$110.2,118.47,120.24,121.89,125.20,126.38,128.31$, $130.44,138.18,138.38,140.92,152.45,161.68$. Compound 5e: Yield (88\%); M.p.: $234^{\circ} \mathrm{C}$; IR $(\mathrm{KBr}), v_{\max }$ $\left(\mathrm{cm}^{-1}\right): 1601(\mathrm{C}=\mathrm{N}), 1698(\mathrm{C}=\mathrm{O})$. TOF-MS ES+ m/z calcd: 458.27. found: $459.34(\mathrm{M}+1)$; Anal. Calcd. for $\mathrm{C}_{19} \mathrm{H}_{16} \mathrm{BrN}_{5} \mathrm{O}_{4}$ : C 49.80, H 3.52, Br 17.44, N 15.28, O 13.97\%. Found: C 49.88, H 3.43, N 15.37\%; ${ }^{1} \mathrm{HNMR}$ $\left(400 \mathrm{MHz}, \mathrm{CDCl}_{3}\right): \delta 1.12\left(\mathrm{t}, 3 \mathrm{H}, \mathrm{COOCH}_{2} \mathrm{CH}_{3}\right), \delta$ $4.10\left(\mathrm{q}, 2 \mathrm{H}, \mathrm{COOCH}_{2} \mathrm{CH}_{3}\right), \delta 6.75(\mathrm{~d}, 2 \mathrm{H}, \mathrm{ArH}), \delta 7.29$

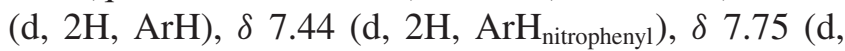
$2 \mathrm{H}, \mathrm{ArH}_{\text {nitrophenyl }}$ ), $\delta 8.21$ (s, 1H, $\mathrm{CH}_{\text {azomethine }}$ ), $\delta 8.24$ (s, $\left.1 \mathrm{H}, \mathrm{CH}_{\text {pyrazole }}\right), \delta 10.55(\mathrm{~s}, 1 \mathrm{H}, \mathrm{NH}) .{ }^{13} \mathrm{C} \mathrm{NMR}\left(\mathrm{CDCl}_{3}\right)$ : $14.7,63.4,110.1,113.7,118.3,124.0,125.1,126.8$, 127.0, 128.1, 132.6, 140.5, 149.8, 150.6, 152.o, 158.7.

\subsection{General procedure for the synthesis of $\mathbf{5 b}$}

To $4 \mathbf{a}(1 \mathrm{~g}, 4.1 \mathrm{mmol})$ in $20 \mathrm{~mL}$ ethanol, 2,4-dinitro phenylhydrazine $(0.972 \mathrm{~g}, 4.9 \mathrm{mmol})$ was added. The reaction mixture was refluxed for $45 \mathrm{~min}$ and then cooled to room temperature. Orange solid was filtered off, washed with hot ethanol $(3 \times 10 \mathrm{~mL})$ and then dried under vacuum to give the desired compound $\mathbf{5 b}$ as orange solid. Compound $\mathbf{5 b}$ : Yield (93\%); M.p.: $232^{\circ} \mathrm{C}$; IR $(\mathrm{KBr}), v_{\max }\left(\mathrm{cm}^{-1}\right): 1598(\mathrm{C}=\mathrm{N})$, $1712(\mathrm{C}=\mathrm{O})$. TOF-MS ES+ m/z calcd: 424.11 found: $425.22(\mathrm{M}+1)$; Anal. Calcd.for $\mathrm{C}_{19} \mathrm{H}_{16} \mathrm{~N}_{6} \mathrm{O}_{6}$ : C 53.77, H 3.80, N 19.80, O 22.62\%. Found: C 53.63, H 3.74, $\mathrm{N} 19.69 \% ;{ }^{1} \mathrm{H}$ NMR $\left(300 \mathrm{MHz}, \mathrm{CDCl}_{3}\right): \delta 1.43(\mathrm{t}, 3 \mathrm{H}$, $\left.\mathrm{COOCH}_{2} \mathrm{CH}_{3}\right), \delta 4.45$ (q, $\left.2 \mathrm{H}, \mathrm{COOCH}_{2} \mathrm{CH}_{3}\right), \delta 7.31$ $(\mathrm{d}, 2 \mathrm{H}, \operatorname{ArH}), \delta 7.73(\mathrm{~d}, 2 \mathrm{H}, \mathrm{ArH}), \delta 7.82(\mathrm{~m}, 1 \mathrm{H}$, ArH), $\delta 8.10$ (m, 1H, $\left.\operatorname{ArH}_{\mathrm{DNP}}\right), \delta 8.29$ (m, 1H, $\mathrm{ArH}_{\mathrm{DNP}}$ ), $\delta 8.67$ (s, 1H, $\left.\mathrm{CH}_{\text {Pyrazole }}\right), \delta 8.93\left(\mathrm{~s}, 1 \mathrm{H}, \mathrm{CH}_{\text {azomethine }}\right)$, $\delta 9.04\left(\mathrm{~m}, 1 \mathrm{H}, \mathrm{ArH}_{\mathrm{DNP}}\right), \delta 11.58(\mathrm{~s}, 1 \mathrm{H}, \mathrm{NH}),{ }^{13} \mathrm{C}$ NMR $\left(\mathrm{CDCl}_{3}\right): 14.4,61.5,103.3,113.7,114.6,119.8$, 124.2, 127.0, 128.7, 130.3, 138.9, 142.5, 147.31, 161.8. Compound 5c: Yield (95\%); M.p.; 235 ${ }^{\circ} \mathrm{C}$; IR (KBr), $v_{\max }\left(\mathrm{cm}^{-1}\right): 1609(\mathrm{C}=\mathrm{N}), 1720(\mathrm{C}=\mathrm{O})$. TOF-MS ES+ $\mathrm{m} / \mathrm{z}$ calcd: 438.39 found:.461.22 $(\mathrm{M}+\mathrm{Na}) ;{ }^{1} \mathrm{H}$ NMR $\left(300 \mathrm{MHz}, \mathrm{CDCl}_{3}\right): \delta 1.29\left(\mathrm{t}, 3 \mathrm{H}, \mathrm{COOCH}_{2} \mathrm{CH}_{3}\right), \delta$ $2.19\left(\mathrm{~s}, 3 \mathrm{H}, \mathrm{CH}_{3}\right), \delta 4.31$ (q, $\left.2 \mathrm{H}, \mathrm{COOCH}_{2} \mathrm{CH}_{3}\right), \delta 7.37-$ 7.46 (m, 4H, ArH), $\delta 8.04$ (m, 2H, $\left.\mathrm{ArH}_{\mathrm{DNP}}\right), \delta 8.76-8.79$ $\left(\mathrm{m}, 2 \mathrm{H}, \mathrm{CH}_{\text {Pyrazole }}+\mathrm{CH}_{\text {azomethine }}\right), \delta 8.99\left(\mathrm{~s}, 1 \mathrm{H}, \mathrm{ArH}_{\mathrm{DNP}}\right)$, $\delta 11.78$ (bs, $1 \mathrm{H}, \mathrm{NH}),{ }^{13} \mathrm{C}$ NMR $\left(\mathrm{CDCl}_{3}\right): 14.4,17.9$, $61.7,116.5,119.9,123.6,126.3,126.9,129.9,130.8$, $131.5,134.0,138.2,138.9,141.2,142.0,144.9,161.3$.

\section{Results and Discussion}

In our effort to prepare receptor molecules $(\mathbf{5 a}-\mathbf{5 e})$, first we prepared 4-formyl-1-substituted phenyl-1 $\mathrm{H}$ pyrazole-3-carboxylate derivatives $(\mathbf{4 a - 4 d})$ in $90-95 \%$ 
yield via two step synthetic protocol. In the first step, alkyl-2-oxopropanoate (1a-1b) reacted with substituted phenyl hydrazine (2a-2b) in presence of trifluroacetic acid in water at room temperature for 5-15 minutes to give 3a-3d in more than $90 \%$ yield. Compound 3a-3d was then reacted with $\mathrm{DMF}-\mathrm{POCl}_{3}$ at $0^{\circ} \mathrm{C}$ to provide 4a-4d in more than $92 \%$ yield. ${ }^{14}$ Reaction of $\mathbf{4 a -}$ 4d with various phenyl hydrazine reagents afforded the receptor $\mathbf{5 a - 5 e}$ in $88-95 \%$ yield as depicted in Scheme 1.

Receptor compounds (5a-5e) were characterized by elemental and spectroscopic analysis. For instance, ${ }^{1} \mathrm{H}$ NMR spectrum of $\mathbf{5 a}$ showed a triplet and quartet at $\delta$ 1.44 and $\delta 4.45$ for $\mathrm{CH}_{3}$ and $\mathrm{CH}_{2}$ protons of ester group, respectively. The azo-methine proton and aromatic proton of pyrazole unit appeared as a non-exchangeable singlet at $\delta 8.43$ and $\delta 8.44$, respectively. The individual assignments of the aromatic proton of pyrazole and azo-methine protons were confirmed by comparison of their spectra with those of precursor compounds. A singlet of $\mathrm{NH}$ protons appeared at $\delta 10.45$ which disappeared on deuteration with $\mathrm{D}_{2} \mathrm{O}$. Similarly, other synthesized compounds were characterized by various spectroscopic techniques.

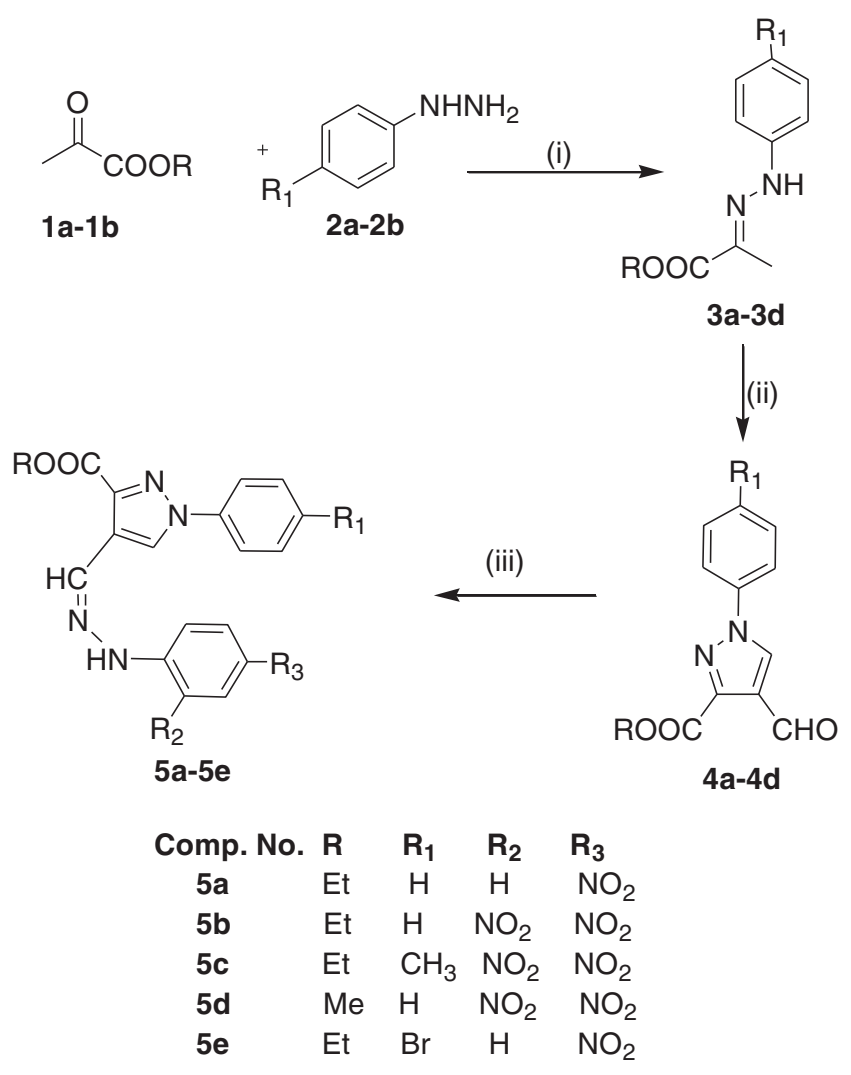

Scheme 1. Synthesis of receptors 5a-5e. Reagents and conditions: (i) TFA, $\mathrm{H}_{2} \mathrm{O}$, room temperature, $15 \mathrm{~min}$; (ii) $\mathrm{DMF}-\mathrm{POCl}_{3}, 0^{\circ} \mathrm{C}, 2.5-3 \mathrm{~h}$; (iii) substituted phenyl hydrazine derivative, ethanol, reflux, 1-2 h.
The anion binding characteristics of receptors $\mathbf{5 a}-\mathbf{5 e}$ with various anions were examined spectrophotometrically and visual colorimetric observation in DMSO$\mathrm{CH}_{3} \mathrm{CN}(1.0: 9.0 \mathrm{v} / \mathrm{v})$. It was observed that receptor $\mathbf{5 a}$ showed an instant change in color from yellow to dark purple with fluoride ion while no change in color was observed with other anions such as $\mathrm{Cl}^{-}, \mathrm{Br}^{-}, \mathrm{I}^{-}, \mathrm{HSO}_{4}{ }^{-}$, $\mathrm{ClO}_{4}{ }^{-}, \mathrm{PF}_{6}{ }^{-}, \mathrm{CH}_{3} \mathrm{COO}^{-}$and $\mathrm{H}_{2} \mathrm{PO}_{4}{ }^{-}$in form of their tetrabutylammonium salts as depicted in Figure 1a. On the other hand, it was observed that receptor $\mathbf{5 b}$ gave a noticeable color change not only with fluoride ion but also with dihydrogen phosphate and acetate anions (Figure 1b) under similar experimental conditions.

The anion binding ability of receptors 5a-5e was also examined by UV-Visible spectroscopy in DMSO$\mathrm{CH}_{3} \mathrm{CN}(1.0: 9.0 \mathrm{v} / \mathrm{v})$ at $\mathrm{pH}$ 7.7. The receptor 5a showed an absorption peak at $402 \mathrm{~nm}$ that could be ascribed to the absorption maximum for the hydrazone unit present in the receptor molecule. The binding characteristics receptor $\mathbf{5 a}$ with various anions was studied by using their tetrabutylammonium salt of $\mathrm{F}^{-}, \mathrm{Cl}^{-}$, $\mathrm{Br}^{-}, \mathrm{I}^{-}, \mathrm{HSO}_{4}^{-}, \mathrm{ClO}_{4}^{-}, \mathrm{PF}_{6}^{-}, \mathrm{CH}_{3} \mathrm{COO}^{-}$and $\mathrm{H}_{2} \mathrm{PO}_{4}{ }^{-}$ in DMSO- $\mathrm{CH}_{3} \mathrm{CN}(1.0: 9.0 \mathrm{v} / \mathrm{v})$. It was observed that receptor 5a selectively recognizes fluoride ion from a mixture of various anions. For example, when $2.2 \times$ $10^{-5} \mathrm{M}$ solution of receptor $\mathbf{5} \mathbf{a}$ was treated with tetrabutyl ammonium fluoride, it showed a bathochromic shift $\left(\Delta \lambda_{\max }\right)$ of $155 \mathrm{~nm}$ in its UV-Visible spectrum with the appearance of a new absorption peak at $557 \mathrm{~nm}$

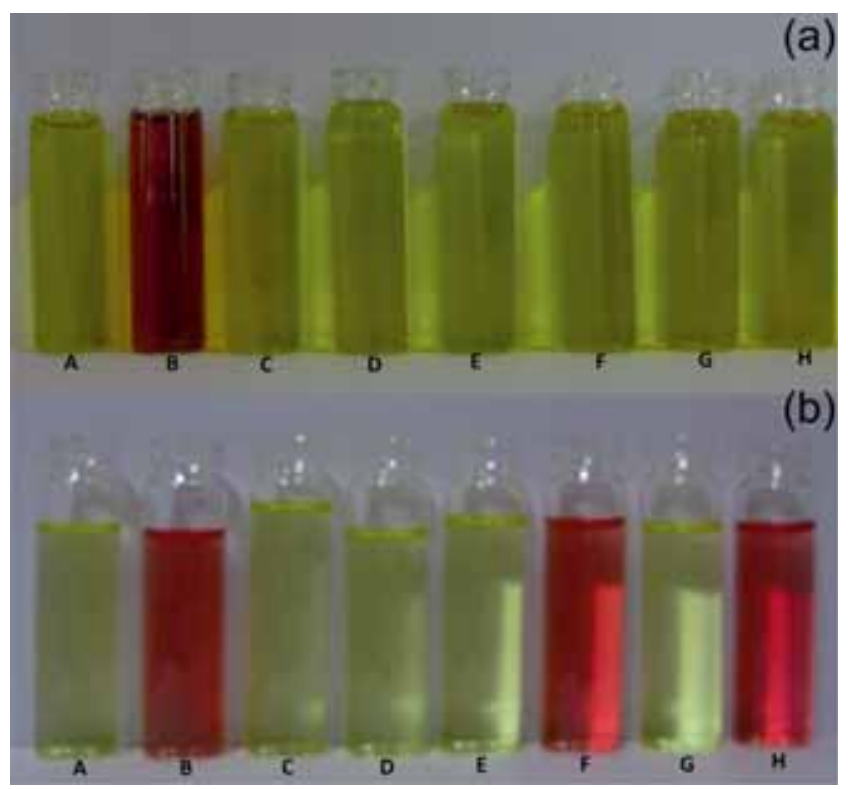

Figure 1. Selectivity of $\mathbf{5 a}$ for fluoride ion over other anions. Color changes of $\mathbf{5 a}$ (a) and $\mathbf{5 b}$ (b) in $(22 \mu \mathrm{M})$ in DMSO: $\mathrm{CH}_{3} \mathrm{CN}(1.0: 9.0 \mathrm{v} / \mathrm{v})$ with the addition of TBA anions $\left(5 \times 10^{-3} \mathrm{M}\right): \mathrm{A}=$ Receptor, $\mathrm{B}=\mathrm{F}^{-}, \mathrm{C}=\mathrm{Cl}^{-}, \mathrm{D}=$ $\mathrm{Br}^{-}, \mathrm{E}=\mathrm{I}^{-}, \mathrm{F}=\mathrm{CH}_{3} \mathrm{COO}^{-}, \mathrm{G}=\mathrm{HSO}_{4}{ }^{-}, \mathrm{H}=\mathrm{H}_{2} \mathrm{PO}_{4}^{-}$. 
while no significant shift in absorption maximum at $402 \mathrm{~nm}$ was observed with other anionic species $\left(\mathrm{Cl}^{-}\right.$, $\mathrm{Br}^{-}, \mathrm{I}^{-}, \mathrm{HSO}_{4}{ }^{-}, \mathrm{ClO}_{4}{ }^{-}, \mathrm{PF}_{6}{ }^{-}, \mathrm{CH}_{3} \mathrm{COO}^{-}$and $\mathrm{H}_{2} \mathrm{PO}_{4}{ }^{-}$) in similar experimental conditions (Figure 2a). These behavior of $5 \mathbf{a}$ could be explained by the formation of more stabilized excited state of $\mathbf{5 a}$ by interaction with fluoride as compared to other anions. ${ }^{12,13}$

Further, it was observed that on gradual addition of a standard solution of tetrabutylammonium fluoride $\left(5 \times 10^{-3} \mathrm{M}\right)$, the intensity of absorption peak at $402 \mathrm{~nm}$ progressively decreased with simultaneous increase in the intensity of absorption peak at $557 \mathrm{~nm}$ in UVVisible spectrum. Critical analysis of UV-Visible titration data indicated that the limiting value of the absorption maximum at $557 \mathrm{~nm}$ was reached at three equivalent of fluoride ion instead of one equivalent (Figure 2b) and the receptor can detect fluoride ion in $\mu \mathrm{M}$ range. These observations can be accounted by the hypothesis that initial addition of one equivalent of fluoride ion establishes a hydrogen bond interaction with $\mathrm{NH}$ proton of the receptor, and further addition of fluoride ion triggers deprotonation of $\mathrm{NH}$ proton, ${ }^{15}$ which results in bathochromic shift in absorption maximum. The change in color occurs possibly through efficient charge transfer from donor to acceptor substituents.
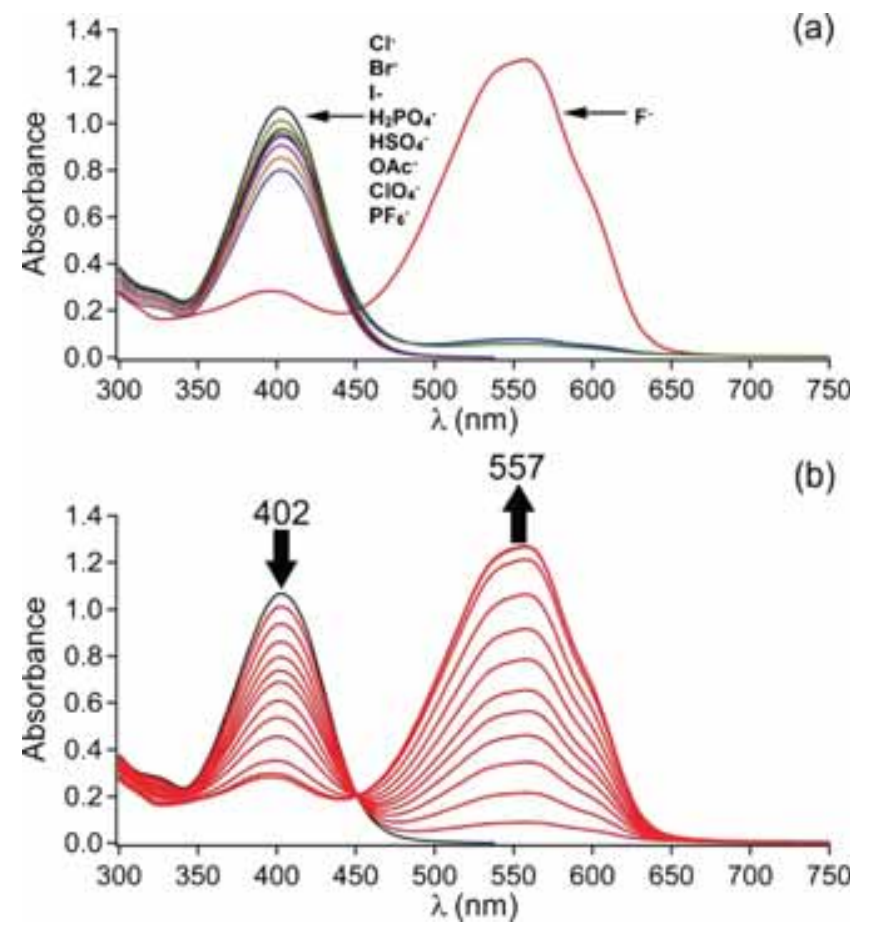

Figure 2. (a) Absorption spectra of $\mathbf{5 a}\left(2.2 \times 10^{-5} \mathrm{M}\right.$, path length of the cuvette $1 \mathrm{~cm}$ ) upon addition of $\mathrm{F}^{-}, \mathrm{Cl}^{-}, \mathrm{Br}^{-}, \mathrm{I}^{-}$, $\mathrm{H}_{2} \mathrm{PO}_{4}^{-}, \mathrm{HSO}_{4}^{-}, \mathrm{CH}_{3} \mathrm{COO}^{-}, \mathrm{ClO}_{4}^{-}$and $\mathrm{PF}_{6}^{-}$ions (tetrabutyammonium salt) $\left(5 \times 10^{-3} \mathrm{M}\right)$ in DMSO- $\mathrm{CH}_{3} \mathrm{CN}(1.0$ : $9.0 \mathrm{v} / \mathrm{v})(\mathrm{b}) \mathrm{UV}-\mathrm{Visible}$ titration of $\mathbf{5 a}$ with 0 to 3 equiv. of $\mathrm{F}^{-}$.
The binding affinity of synthesized receptor 5a towards fluoride ion was again examined by ${ }^{1} \mathrm{H}$ NMR titration experiments in $\mathrm{CDCl}_{3}$. The ${ }^{1} \mathrm{H}$ NMR spectrum of $\mathbf{5} \mathbf{a}$ on gradual addition of tetrabutylammonium fluoride (Figure 3 ) indicated that addition of fluoride ions a broadening of hydrazone NH signal and a downfield shift in methine proton of pyrazole and aromatic proton of phenyl unit (attached to pyrazole moiety) was observed whereas an unexpected upfield shift in aromatic proton of nitrophenyl moiety was observed. Analysis of the ${ }^{1} \mathrm{H}$ NMR titration spectra indicated that addition of increasing equivalent of $\mathrm{F}^{-}$ions to $\mathbf{5 a}$ results in a broadening of hydrazone $\mathrm{NH}$ signals at $\delta 10.45$ which completely disappeared after the addition of two equivalents of fluoride ions with appearance of a broad signal at $16 \mathrm{ppm}$ in ${ }^{1} \mathrm{H}$ NMR spectrum that could be ascribed to the formation of stable bifluoride $\left[\mathrm{HF}_{2}^{-}\right] .{ }^{16}$ However, addition of fluoride ions more than two equivalents to the solution of $\mathbf{5} \mathbf{a}$ resulted in upfield chemical shift in aromatic proton at $\delta 8.11$ of the nitro phenyl units while downfield chemical shift in methine proton of pyrazole at $\delta 8.41$ and aromatic proton of phenyl unit at $\delta 7.14$ which reached its limiting value on addition of three equivalents of fluoride ion. These experimental observations indicate that initial one equivalent of fluoride ion interact through hydrogen bonds with the $\mathrm{NH}$ protons of hydrazone subunits of receptor 5a whereas addition beyond one equivalent of fluoride results in the deprotonation of the $\mathrm{NH}$ protons to induce an upfield shift of the aromatic proton of nitrophenyl unit due

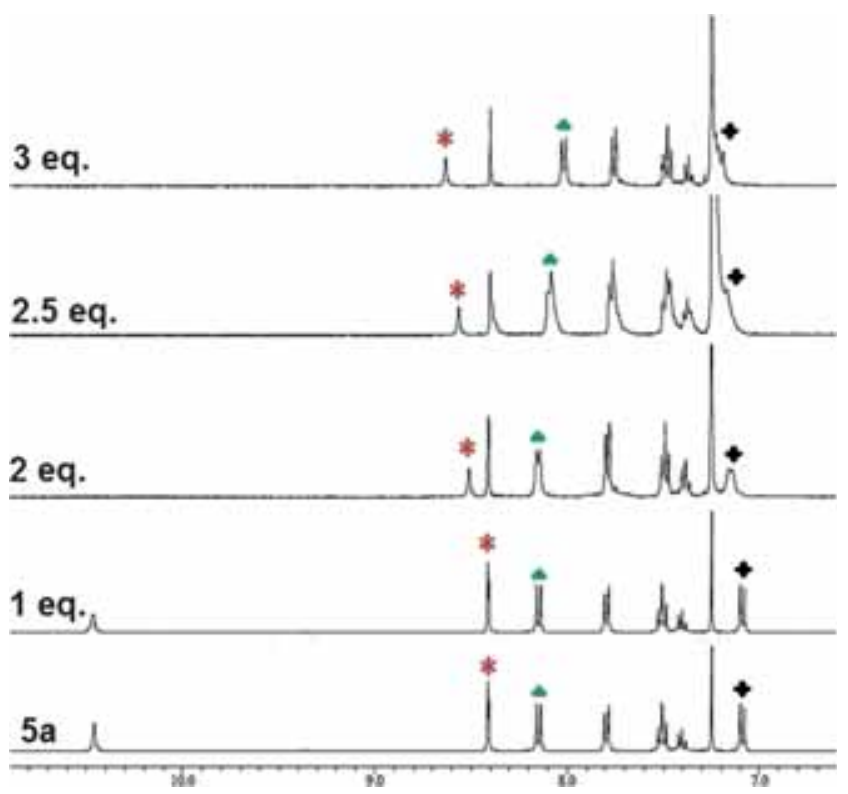

Figure 3. Partial ${ }^{1} \mathrm{H} \mathrm{NMR}\left(400 \mathrm{MHz}, \mathrm{CDCl}_{3}\right)$ spectra of 5a $(15 \mathrm{mM})$ upon addition of various equiv. of TBAF (45 $\mathrm{mM})$. Numbers at left side indicate the equivalent amount of $\mathrm{F}^{-}$added $\left(*=\mathrm{ArH}_{\text {pyrazole }}, \boldsymbol{\bullet}=\mathrm{ArH}_{\text {nitrophenyl }}, \boldsymbol{*}=\mathrm{ArH}\right)$. 


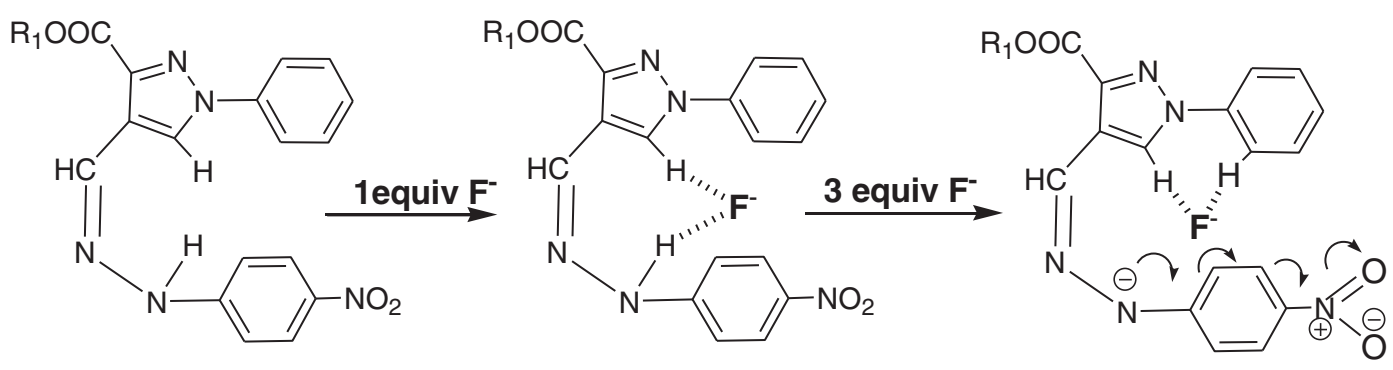

Scheme 2. A proposed binding mode and deprotonation of 5a with fluoride ion.

Table 1. Shift in absorption peak $\left(\lambda_{\max }\right)$ for receptors $\mathbf{5 a}-\mathbf{e}$ with the fluoride ion ${ }^{\mathrm{a}}$.

\begin{tabular}{lccc}
\hline Receptor $(\mathrm{L})$ & $\lambda_{\max } / \mathrm{nm}(\mathrm{L})^{\mathrm{a}}$ & $\lambda_{\max } / \mathrm{nm}\left(\mathrm{L}+\mathrm{F}^{-}\right)$ & $\Delta \lambda_{\max } / \mathrm{nm}$ \\
\hline 5a & 402 & 557 & 155 \\
$\mathbf{5 b}$ & 386 & 492 & 106 \\
$\mathbf{5 c}$ & 385 & 493 & 108 \\
$\mathbf{5 d}$ & 385 & 492 & 107 \\
5e & 401 & 556 & 155 \\
\hline
\end{tabular}

a Absorption spectra were taken at a concentration of $22 \mu \mathrm{M}$ in DMSO-CH 3 CN (1.0: $9.0 \mathrm{v} / \mathrm{v})$ solution.

to through-bond propagation of electron density. The downfield shift of methine proton and aromatic proton of the phenyl unit on addition of three equivalents of fluoride ion in $\mathrm{CDCl}_{3}$ indicated that both the methine and aromatic protons of phenyl unit participate in the formation of cooperative hydrogen bonds with anionic guest (Scheme 2). ${ }^{17}$

Similar experiments were performed with $\mathbf{5 b}, \mathbf{5 c}$ and 5d. It was observed that these receptors exhibited bathochromic shifts of lower magnitude as compared to $\mathbf{5 a}$ and $\mathbf{5 e}$ in the UV-Visible spectrum with fluoride ions (Table 1), possibly due to the extended conjugation present in 5a and 5e. Additionally, it was interesting to observe that receptors $\mathbf{5 b}, \mathbf{5 c}$ and $\mathbf{5 d}$ showed bathochromic shifts of similar magnitude in their $\lambda_{\max }$ values on addition of tetrabutylammoniumdihydrogen phosphate and acetate ions as shown in Figure 4. The additional binding ability of receptors $\mathbf{5 b}$ and $\mathbf{5 d}$ for dihydrogen phosphate and acetate ions can possibly be ascribed to the comparatively more acidic nature of the NH protons due to the presence of two electron withdrawing nitro substituents. The UV-Visible titration experiments of receptor $\mathbf{5 b}$ with $\mathrm{F}^{-}$ion indicated that intensity of absorption at $386 \mathrm{~nm}$ progressively decreased with gradual appearance of a new peak at $492 \mathrm{~nm}$ along with a color change from yellow to purple which reached a saturation point on addition of three equivalents of fluoride ions (Figure S1, see Supplementary Information).

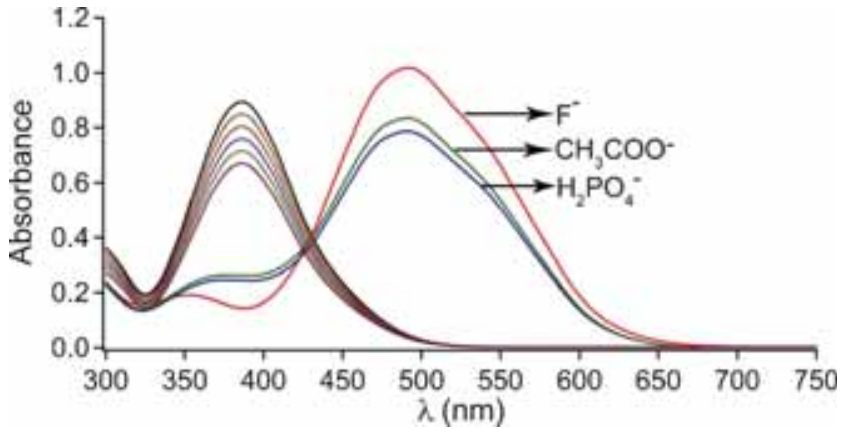

Figure 4. Absorption spectra of $\mathbf{5 b}\left(2.2 \times 10^{-5} \mathrm{M}\right.$, path length of the cuvette $1 \mathrm{~cm}$ ) upon addition of $\mathrm{F}^{-}, \mathrm{Cl}^{-}, \mathrm{Br}^{-}, \mathrm{I}^{-}$, $\mathrm{H}_{2} \mathrm{PO}_{4}{ }^{-}, \mathrm{HSO}_{4}{ }^{-}, \mathrm{CH}_{3} \mathrm{COO}^{-}, \mathrm{ClO}_{4}^{-}$and $\mathrm{PF}_{6}^{-}$ions (tetrabutyammonium salt $)\left(5 \times 10^{-3} \mathrm{M}\right)$ in DMSO-CH $3 \mathrm{CN}(1.0$ : $9.0 \mathrm{v} / \mathrm{v})$.

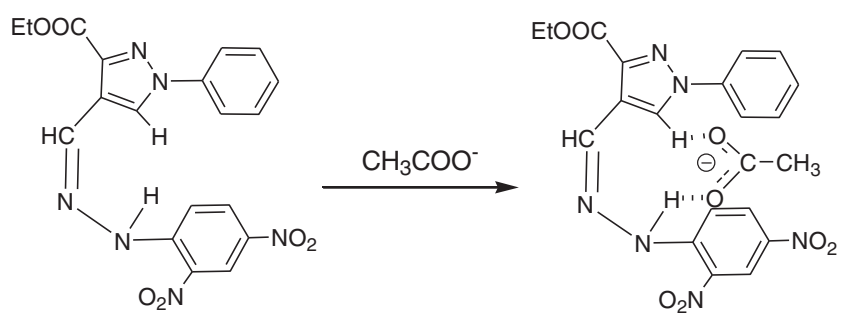

Scheme 3. A proposed binding mode of $\mathbf{5 b}$ with acetate ion.

Similarly, the titration profiles of $\mathbf{5 b}$ with $\mathrm{CH}_{3} \mathrm{COO}^{-}$ and $\mathrm{H}_{2} \mathrm{PO}_{4}{ }^{-}$ion was further studied from UVvisible spectrum in $\mathrm{DMSO}-\mathrm{CH}_{3} \mathrm{CN}(1.0: 9.0 \mathrm{v} / \mathrm{v})$. A bathochromic shift $\left(\Delta \lambda_{\max }\right)$ of $105 \mathrm{~nm}$ in its UV-Visible spectrum was observed with the appearance of a new absorption peak at $491 \mathrm{~nm}$ which reached the limiting values on addition of two equivalents of the respective anions (Figures S2 and S3). These observations suggest that the $\mathrm{F}^{-}$ion interact with $\mathbf{5} \mathbf{b}$ in a similar manner as that of 5a, while the $\mathrm{CH}_{3} \mathrm{COO}^{-}$and $\mathrm{H}_{2} \mathrm{PO}_{4}{ }^{-}$ ions interact with $\mathbf{5 b}$ exclusively through hydrogen bonding (Scheme 3). The receptors $\mathbf{5 e}$ and $\mathbf{5 d}$ showed similar behavior in the colorimetric and UV-Visible experiments as that of $\mathbf{5} \mathbf{a}$ and $\mathbf{5 b}$, respectively, thereby suggesting that the aromatic proton of the phenyl unit 
(attached to pyrazole) (in $\mathbf{5 a}$ and $\mathbf{5 b}$ ) when replaced by methyl and bromine (in $\mathbf{5 c}$ and $\mathbf{5 e}$ ), respectively, do not affect the binding mode of anions.

\section{Conclusions}

In conclusion, a new class of efficient colorimetric chemosensors derived from 4-[(nitro substituted-phenyl)hydrazonomethyl]-1-phenyl-1 $H$-pyrazole-3-carboxylate $(\mathbf{5 a}-\mathbf{5 e})$ have been synthesized and characterized. The synthesized receptors exhibit significant bathochromic shifts when interacted with fluoride ions along with prominent color change. The UV-Visible and ${ }^{1} \mathrm{H}$ NMR titration experiments revealed that receptor $\mathbf{5 a}$ and $\mathbf{5 e}$ showed selective sensing of fluoride ions via hydrogen bond interaction in preference to $\mathrm{Cl}^{-}, \mathrm{Br}^{-}, \mathrm{I}^{-}, \mathrm{HSO}_{4}^{-}$, $\mathrm{ClO}_{4}{ }^{-}, \mathrm{PF}_{6}{ }^{-}, \mathrm{CH}_{3} \mathrm{COO}^{-}$and $\mathrm{H}_{2} \mathrm{PO}_{4}^{-}$ions whereas receptors $\mathbf{5 b}, \mathbf{5 c}$ and $\mathbf{5 d}$ showed sensing of acetate and dihydrogenphosphate ions along with fluoride ion in organic media.

\section{Acknowledgements}

RS and AA acknowledge Manipal University Jaipur for seed money grant. SS acknowledges MUJ for a teaching assistantship. Material Research Center, MNIT, Jaipur is gratefully acknowledged for recording NMR, FT-IR and Mass spectra reported in this paper.

\section{References}

1. (a) Frontera A 2013 Coord. Chem. Rev. 257 1716; (b) Chandel M, Roy S M, Sharma D, Sahoo S K, Patel A, Kumari P, Dhale R S, Ashok K S K, Nandre J P and Patil U D 2014 J. Lumin. 154 515; (c) Pandian T S and Kang J 2015 Tetrahedron Lett. 56 4191; (d) Kumari N and Zelder F 2015 Chem. Commun. 51 17170; (e) Bose P, Dutta R, Ravikumar I and Ghosh P 2011 J. Chem. Sci. 123869

2. (a) Ieda N, Nakagawa H, Peng T, Yang D, Suzuki T and Miyata N 2012 J. Am. Chem. Soc. 134 2563; (b) Kaur K, Saini R, Kumar A, Luxami V, Kaur N, Singh P and Kumar S 2012 Coord. Chem. Rev. 256 1992; (c) Wang J, Bai F-Q, Xia B-H, Sun L and Zhang H-X 2011 J. Phys. Chem. A 115 1985; (d) Kang Y, Gwon K, Shin J H, Nam H, Meyerhoff M E and Cha G S 2011 Anal. Chem. 83 3957; (e) Nieto D, González-Vadillo M A, Bruña S, Pastor C J, Kaifer A E and Cuadrado I 2011 Chem. Commun. 47 10398; (f) Duke R M, Veale E B, Pfeffer F M, Kruger P E and Gunnlaugsson T 2010 Chem. Soc. Rev. 39 3936; (g) Hu S, Guo Y, Xu Y and Shao S 2008 Org. Biomol. Chem. 6 2071; (h) Peng T and Yang D 2010 Org. Lett. 12 4932; (i) Guha S and Saha S 2010 J. Am. Chem. Soc. 132 17674; (j) Kikuchi K, Hashimoto S, Mizukami S and Nagano T 2009 Org. Lett. 112732
3. (a) Gai L, Mack J, Lu H, Nyokong T, Li Z, Kobayashi $\mathrm{N}$ and Shen Z 2015 Coord. Chem. Rev. 285 24; (b) Pandurangan K, Kitchen J A and Gunnlaugsson T 2013 Tetrahedron Lett. 54 2770; (c) Zhou Y, Dong X, Zhang Y, Tong P and Qu J 2016 Dalton Trans. 45 6839; (d) Borah S, Konwar G, Borborah A and Gogoi N 2015 $R S C A d v .5$ 101701; (e) Yan G T, Li H, Zhu Y R, Shi B B, Qu W, Lin Q, Yao H, Zhang Y M and Wei T B 2015 New J. Chem. 39 8797; (f) Datta B K, Kar C and Das G 2015 J. Chem. Sci. 127337

4. (a) Zhang J F, Lim C S, Bhuniya S, Cho B R and Kim J S 2011 Org. Lett. 13 1190; (b) Swamy K M K, Lee Y J, Lee H N, Chun J, Kim Y, Kim S-J and Yoon J 2006 J. Org. Chem. 71 8626; (c) Gerlach R F, de Souza A P, Cury J A and Line S R P 2000 Eur. J. Oral Sci. 10848

5. (a) Kirk K L 1991 In Biochemistry of the Halogens and Inorganic Halides (New York: Plenum Press) p 58; (b) Weatherall J A 1969 In Pharmacology of Fluorides In Handbook of Experimental Pharmacology XX/1 (Berlin: Springer-Verlag) Part 1, pp. 141-172; (c) Kleerekoper M 1998 Endocrinol. Metab. Clin. North Am. 27441

6. (a) Gale P A 2001 Coord. Chem. Rev. 213 79; (b) Gale P A 2003 Coord. Chem. Rev. 240 1; (c) Sessler J L and Davis J M 2001 Acc. Chem. Res. 34 989; (d) Gale P A 1998 Coord. Chem. Rev. 199 181; (e) Beer P D and Gale P A 2001 Angew. Chem. Int. Ed. 40486

7. (a) Gale P A 2001 Acc. Chem. Res. 39 465; (b) Chmielewski M J and Jurczak J 2005 Chem. Eur. J. 11 6080; (c) Ghosh B and Maiya B G 2004 J. Chem. Sci. 11617

8. (a) Liu S, Kang J, Cao X and Yue X 2016 Spectrochim. Acta Part A 153 471; (b) Gunnlaugsson T, Glynn M, Tocci (née Hussey) G M, Kruger P E and Pfeffer F M 2006 Coord. Chem. Rev. 2503094

9. (a) Bregović V B, Basarić N and Mlinarić-Majerski K 2015 Coord. Chem. Rev. 295 80; (b) Khansari M E, Wallace K D and Hossain M A 2015 Tetrahedron Lett. $\mathbf{5 5} 438$

10. (a) Lee D H, Lee K H and Hong J-I 2001 Org. Lett. 3 5; (b) Lee C, Lee D H and Hong J-I 2001 Tetrahedron Lett. 42 8665; (c) Lee D H, Lee H Y, Lee K H and Hong J-I 2001 Chem. Commun. 1188; (d) Martinez-Manez R and Sancenon F 2003 Chem. Rev. 103 4419; (e) Gomez D E, Fabbrizzi L and Licchelli M 2005 J. Org. Chem. 70 5717; (f) Cho E J, Ryu B J, Lee Y J and Nam K C 2005 Org. Lett. 7 2607; (g) Kim S Y and Hong J-I 2007 Org. Lett. 9 3109; (h) Lin Z, Ou S, Duan C, Zhang B and Bai Z 2006 Chem. Commun. 624

11. (a) Damljanovic I, Vukicevic M, Radulovic N, Palic R, Ellmerer E, Ratkovic Z, Joksovic M D and Vukicevic R D 2009 Bioorg. Med. Chem. Lett. 19 1093; (b) Abadi A H, Eissa A A and Hassan G S 2003 Chem. Pharm. Bull. 51 838; (c) Bekhit A A, Ashour H M A, Ghany Y S A, Bekhit A E A and Baraka A 2008 Eur. J. Med. Chem. 43 456; (d) Chovatia P T, Akabari J D, Kachhadia P K, Zalawadia P D and Joshi H S 2007 J. Serb. Chem. Soc. 71 713; (e) Rathelot P, Azas N, El-Kashef H, Delmas F, Giorgio C D, Timon-David P, Maldonado J and Vanelle P 2002 Eur. J. Med. Chem. 37 671; (f) Prakash O, Kumar R and Sehrawat R 2009 Eur. J. Med. Chem. 44 1763; (g) Hashem A I, Youssef A S A, 
Kandeel K A and Abou-Elmagd W SI 2007 Eur. J. Med. Chem. 42934

12. (a) Chawla H M, Sahu S N and Shrivastava R 2007 Tetrahedron Lett. 48 6054; (b) Chawla H M, Sahu S N, Shrivastava R and Kumar S 2012 Tetrahedron Lett. 53 2244; (c) Chawla H M, Sahu S N, Shrivastava R, Kumar S and Upreti S 2012 Supramol. Chem. 24672

13. (a) Chen Y C, Liu X X, Huang H, Wu W W and Zheng Y S 2010 Sci. China: Chem. 53 569; (b) Saravanakumar D, Devraj S, Iyyampillai S, Mohandoss K and Kandaswamy M 2008 Tetrahedron Lett. 49127

14. Swami S, Devi N, Agarwala A, Singh V and Shrivastava R 2016 Tetrahedron Lett. 571346

15. (a) Amendola V, Boiocchi M, Colasson B and Fabbrizzi L 2006 Inorg. Chem. 45 6138; (b) Peng X, Wu Y, Fan J, Tian M and Han K 2005 J. Org. Chem. 70 10524; (c) Ghosh T, Maiya B G and Wong MW 2004 J. Phys. Chem. A 108 11249; (d) Gunnlaugsson T, Kruger P E, Jensen P, Tierney J, Ali H D P and Hussey G M 2005 J. Org. Chem. 7010875

16. (a) Kang S O, Powell D, Day V W and Bowman-James K 2006 Angew. Chem. Int. Ed. 45 1921; (b) Linares J M, Powell D and Bowman-James K 2003 Coord. Chem. Rev. 240 57; (c) Gronert S 1993 J. Am. Chem. Soc. 115 10258; (d) Torrent-Sucarrat M, Duran M, Luis J M and Solà M 2005 J. Chem. Sci. 117549

17. (a) Haridas V, Sahu S and Kumar P P P 2011 Tetrahedron Lett. 52 6930; (b) Kim J S, Park S Y, Kim S H, Thuéry P, Souane R, Matthews S E and Vicens J 2010 Bull. Korean Chem. Soc. 31 624; (c) Wang Y, Bie F and Jiang H 2010 Org. Lett. 12 3630; (d) Hua Y and Flood A H 2010 Chem. Soc. Rev. 391262 